\title{
Ocular manifestations of Alport's syndrome: a hereditary disorder of basement membranes?*
}

\author{
J. A. A. GOVAN
}

From the Department of Ophthalmology, Guy's Hospital, London SE1

SUMmARY The ocular manifestations in 16 patients with Alport's syndrome were lenticonus and retinal flecks in the macula and mid periphery. These 3 features appear to be specific for this syndrome and are a considerable aid to diagnosis. Lens opacities are common, and other ocular abnormalities occur sporadically. The present evidence indicates that this is a hereditary, widespread disorder of basement membrane, and it is suggested that ophthalmologists may contribute to the further understanding of it by directing attention towards analysis of the lens capsule after cataract extraction. The similarity of the retinopathy to that of fundus albipunctatus is noted, and it is suggested that the latter condition should not be diagnosed in the absence of renal investigation and audiometry.

Alport's syndrome ${ }^{1-3}$ is clinically characterised by the familial occurrence of progressive, haematuric nephritis and sensorineural deafness in which the renal prognosis is better in female patients. Ocular features most frequently described include lens abnormalities $^{4}$ characterised by lenticonus ${ }^{5-7}$ and cataract, central and midperipheral retinal flecks, ${ }^{8-17}$ and corneal arcus. ${ }^{6716-18}$ Most previous ophthalmic reports have tended to concentrate on an isolated ocular manifestation of this syndrome.

This paper describes the detailed ocular findings in 16 patients who have been treated in the Renal Departments at Guy's Hospital and attempts to differentiate the nonspecific from the specific ocular features that occur in this syndrome.

\section{Patients and methods (Table 1)}

The diagnosis of Alport's syndrome was based on the presence of chronic renal failure and the presence of bilateral sensorineural deafness which in most cases was confirmed by audiometry. Twelve patients had a positive family history of renal disease, and all cases except 2 (patients 5 and 11) had suffered from hypertension in the past, which was controlled at the time of examination. The average age at examination was 24 years (range 16-39 years), and the average age at

* Presented in part at the 24th International Congress of Ophthalmology, 1982, San Francisco. Correspondence to Mr J. A. A. Govan. which renal failure necessitated maintenance dialysis or renal transplantation supervened (13/16 patients) was 21 years (range 13-35 years). Nine of these patients at the time of examination had a renal transplant which had been successfully functioning for an average 4 years (range 6/12-7 years), whereas the remaining 4 were on maintenance dialysis. All except one of the latter group had renal transplants which were either successful or had subsequently rejected, and consequently 12 of the whole group had been on immunosuppressives and systemic steroids in the past. One patient had associated macrothrombocytopenia. ${ }^{19}$

Ocular examination included subjective and objective refraction with best visual acuity and biomicroscopy of the anterior segment. The posterior segment was studied by both indirect ophthalmoscopy and by biomicroscopy with a fundus contact lens. Fundus photography was undertaken in 12 patients and fluorescein angiography in 7 selected cases. An electroretinogram (ERG) was recorded in both light and dark adapted states using skin electrodes in 5 patients with a flash intensity of 0.2 Joules and a recording band width of 1 to $100 \mathrm{~Hz}$. An electrooculogram (EOG) was recorded in 4 patients after dark adaptation and during light adaptation to obtain maximum light: minimum dark ratios. Serum triglycerides, cholesterol, vitamin A and plasma amino acid levels were measured after an overnight fast. 
Table 1 Ocular features and serum vitamin A levels

\begin{tabular}{|c|c|c|c|c|c|c|c|c|c|}
\hline \multirow[t]{2}{*}{ Patient } & \multicolumn{2}{|l|}{ Age $(y r)$} & \multirow[t]{2}{*}{ Sex } & \multirow[t]{2}{*}{ Renal status } & \multirow[t]{2}{*}{$\begin{array}{l}\text { Family } \\
\text { history }\end{array}$} & \multicolumn{2}{|c|}{$\begin{array}{l}\text { Corrected visual } \\
\text { acuity }\end{array}$} & \multirow{2}{*}{$\begin{array}{l}\text { Corneal arcus } \\
+=\text { Microscopic } \\
++=\text { Macroscopic }\end{array}$} & \multirow{2}{*}{$\begin{array}{l}\text { Lenticonus } \\
++=\text { Definite } \\
+=\text { Probable }\end{array}$} \\
\hline & $\begin{array}{l}\text { at } \\
\text { examination }\end{array}$ & $\begin{array}{l}\text { at renal } \\
\text { failure }\end{array}$ & & & & $O D$ & $O S$ & & \\
\hline 1 & 21 & 21 & $\mathbf{M}$ & Dialysis & + & $6 / 9$ & $6 / 12$ & - & - \\
\hline 2 & 30 & 22 & $\mathbf{M}$ & $\begin{array}{l}\text { Failed } \\
\text { transplant } \\
\rightarrow \text { Dialysis }\end{array}$ & + & $6 / 5$ & $6 / 5$ & ++ & + \\
\hline 3 & 33 & 22 & M & $\begin{array}{l}\text { Functioning } \\
\text { transplant }\end{array}$ & + & $6 / 9$ & $6 / 9$ & ++ & + \\
\hline 4 & 28 & 22 & $\mathbf{M}$ & $\begin{array}{l}\text { Functioning } \\
\text { transplant }\end{array}$ & + & $6 / 9$ & $6 / 9$ & ++ & + \\
\hline 5 & 16 & - & $\mathbf{M}$ & - & + & $6 / 9$ & $6 / 9$ & + & - \\
\hline 6 & 33 & 29 & $\mathbf{M}$ & $\begin{array}{l}\text { Functioning } \\
\text { transplant }\end{array}$ & + & $6 / 6$ & $6 / 6$ & ++ & ++ \\
\hline 7 & 18 & - & $\mathbf{M}$ & - & + & $6 / 12$ & $6 / 9$ & - & - \\
\hline 8 & 20 & 13 & $\mathbf{M}$ & $\begin{array}{l}\text { Functioning } \\
\text { transplant }\end{array}$ & - & $6 / 9$ & $6 / 9$ & ++ & ++ \\
\hline 9 & 19 & - & $F$ & - & + & $6 / 9$ & $6 / 9$ & - & ++ \\
\hline 10 & 14 & 14 & $\mathbf{M}$ & $\begin{array}{l}\text { Functioning } \\
\text { Transplant }\end{array}$ & - & $6 / 9$ & $6 / 6$ & - & - \\
\hline 11 & 39 & 35 & $\mathbf{M}$ & $\begin{array}{l}\text { Functioning } \\
\text { transplant }\end{array}$ & $?$ & $6 / 24$ & $6 / 9$ & + & - \\
\hline 12 & 16 & 14 & $\mathbf{M}$ & $\begin{array}{l}\text { Functioning } \\
\text { transplant }\end{array}$ & + & $6 / 9$ & $6 / 9$ & - & - \\
\hline 13 & 19 & 14 & $\mathbf{M}$ & $\begin{array}{l}\text { Failed } \\
\text { transplant } \\
\rightarrow \text { Dialysis }\end{array}$ & + & $6 / 9$ & $6 / 18$ & - & ++ \\
\hline 14 & 34 & 32 & $\mathbf{M}$ & $\begin{array}{l}\text { Failed } \\
\text { transplant } \\
\rightarrow \text { Dialysis }\end{array}$ & + & $6 / 6$ & $6 / 6$ & ++ & - \\
\hline 15 & 24 & 20 & $\mathbf{M}$ & $\begin{array}{l}\text { Functioning } \\
\text { transplant }\end{array}$ & + & $6 / 12$ & $6 / 9$ & - & - \\
\hline 16 & 20 & 13 & $\mathbf{M}$ & $\begin{array}{l}\text { Functioning } \\
\text { transplant }\end{array}$ & - & $6 / 6$ & $6 / 9$ & ++ & + \\
\hline
\end{tabular}

*Upper limit of normal $=0.7 \mathrm{mg} / \mathrm{l}$.

Results (Table 1)

VISUAL ACUITY

The visual acuities were generally compatible with the degree of lens opacity present, though 5 of the 6 patients with clear ocular media had slightly reduced corrected vision (6/9-6/12). Although 3 of these patients had lenticonus, in none of the 5 patients did the acuity improve with a pinhole. Five patients had myopia $(>2.00 \mathrm{D})$, and 3 of these and 5 other patients had myopic astigmatism $(>2.00 \mathrm{D})$. One patient had hypermetropic astigmatism $(>2.00 \quad \mathrm{D})$. These refractions were bilateral and tended to be symmetrical. One patient had a strabismic amblyopic eye. No history of definite night blindness was elicited, though every patient was specifically questioned.

CORNEA

Nine out of 16 patients, who were on average $9 \cdot 4$ years older than the remaining patients, had a bilateral symmetrical corneal arcus tending to spare the interpalpebral region. This was well defined in 7 patients but visible only microscopically in 2 patients. One patient (patient 11) had a definite bilateral increase of the normal corneal stromal granular appearance.

\section{LENS}

Anterior lenticonus was diagnosed by the characteristic anterior axial projection of the central $3-4 \mathrm{~mm}$ of the lens seen on biomicroscopy and the 'oil droplet' appearance of the red reflex. Two patients (patients 8 and 13) satisfied both these criteria, one of whom had an abnormal shagreen of the central anterior lens capsule bilaterally. Four patients (patients 2, 3, 4, and 16) displayed only the oil droplet appearance, which was in one patient (patient 2) apparent only on oblique viewing, and 2 patients (patients 6 and 9 ) had definite biomicroscopic evidence of anterior lenticonus with the oil droplet appearance evident only on oblique viewing. In each case the appearance 


\begin{tabular}{|c|c|c|c|c|c|c|c|}
\hline Cataract & $\begin{array}{l}\text { Macular } \\
\text { flecks }\end{array}$ & $\begin{array}{l}\text { Mid peripheral } \\
\text { flecks }\end{array}$ & $E R G$ & $E O G$ & $\begin{array}{l}\text { Fundus } \\
\text { photography }\end{array}$ & $\begin{array}{l}\text { Vitamin A } \\
\text { levels } \\
(m g / l)^{*}\end{array}$ & Comment \\
\hline- & - & - & & & - & $1 \cdot 1$ & Preretinal membrane \\
\hline $\begin{array}{l}\text { Post. } \\
\text { polar }\end{array}$ & + & - & & & $\begin{array}{l}\text { Colours } \\
\text { only }\end{array}$ & 1.0 & \\
\hline Cortical & - & ++ & & & $\begin{array}{l}\text { Colours } \\
\text { only }\end{array}$ & $0 \cdot 8$ & Brothers \\
\hline - & ++ & ++ & & & $\begin{array}{l}\text { Colours + } \\
\text { fluorescein }\end{array}$ & - & \\
\hline Lamellar & + & - & & & - & 0.9 & \\
\hline $\begin{array}{l}\text { Ant. subcaps. } \\
\text { cortical }\end{array}$ & ++ & ++ & Normal & Normal & $\begin{array}{l}\text { Colours + } \\
\text { fluorescein }\end{array}$ & 0.9 & Preretinal membrane \\
\hline- & + & - & & & $\begin{array}{l}\text { Colours }+ \\
\text { fluorescein }\end{array}$ & - & \\
\hline $\begin{array}{l}\text { Post. } \\
\text { subcapsular }\end{array}$ & $\begin{array}{l}++ \\
-\end{array}$ & $\stackrel{+}{-}$ & & & $\begin{array}{l}\text { Colours } \\
\text { only }\end{array}$ & $1 \cdot 3$ & \\
\hline- & - & + & & & $\div$ & - & \\
\hline - & + & + & & & $\begin{array}{l}\text { Colours } \\
\text { only }\end{array}$ & $1 \cdot 0$ & \\
\hline $\begin{array}{l}\text { Post. + ant. } \\
\text { subcapsular } \\
\text { Dot }\end{array}$ & - & ++ & & Normal & $\begin{array}{l}\text { Colours + } \\
\text { fluorescein }\end{array}$ & $1 \cdot 1$ & Amblyopic OD \\
\hline $\begin{array}{l}\text { Post. } \\
\text { subcapsular } \\
\text { Cortical }\end{array}$ & + & - & Normal & Normal & $\begin{array}{l}\text { Colours + } \\
\text { fluorescein }\end{array}$ & - & \\
\hline $\begin{array}{l}\text { Post. + ant. } \\
\text { subcapsular } \\
\text { Dot }\end{array}$ & - & - & . & & $\begin{array}{l}\text { Colours + } \\
\text { fluorescein }\end{array}$ & $0 \cdot 8$ & Half-brothers, anisocoria \\
\hline- & - & + & & & - & - & \\
\hline $\begin{array}{l}\text { Post. } \\
\text { subcapsular }\end{array}$ & + & - & Normal & Normal & $\begin{array}{l}\text { Colours + } \\
\text { fluorescein }\end{array}$ & 0.9 & Macrothrombocytopenia \\
\hline $\begin{array}{l}\text { Post. } \\
\text { subcapsular }\end{array}$ & ++ & ++ & Normal & Normal & $\begin{array}{l}\text { Colours } \\
\text { only }\end{array}$ & $1 \cdot 1$ & \\
\hline
\end{tabular}

was identical on both sides, and no case of true posterior lenticonus was seen. Four of this group (patients 2, 3, 4, and 13) had noticed that their vision was blurred in bright sunlight, whereas one patient (patient 8) complained that his vision was blurred for about 10 minutes after awakening each morning. Four patients had symptoms of myopia, which had gradually progressed in one patient over 16 years, and one patient (patient 6) had bilateral uniocular diplopia which was correctable with lenses.

Ten patients displayed lens opacities. Six patients, all of whom had been on systemic steroids in the past, had posterior subcapsular lens opacities. Other lens opacities included anterior axial subcapsular, posterior polar, and anterior and posterior axial cortical opacities, and one patient had bilateral lamellar lens opacities of $6 \cdot 2 \mathrm{~mm}$ diameter in which the posterior lamellar opacity bowed posteriorly axially in what has been called an internal lenticonus. ${ }^{20}$ Also seen were anterior and posterior subcapsular vacuolation and blue dot opacities.

\section{FUNDI}

Flecks were seen in 14 patients. Macular flecks were seen in 10 cases, of which 6 cases on clinical examination showed only sparse flecks lying mainly in the temporal region (Fig. 1). These appeared more widespread, however, when the fundus photographs were examined, and in one case this was the only means of seeing the flecks. The remaining 4 patients showed more profuse macular flecks which were found in an oval distribution, the widest radius being horizontal and beginning $0.5-0.6 \mathrm{~mm}$ from the foveal pit, tending to spare the foveolar and central parafoveal region. These flecks were a pale yellow colour, round, 20-50 $\mu \mathrm{m}$ diameter, and on biomicroscopic examination appeared in the innermost layer of the retina. The flecks in patient 10 extended $1.2 \mathrm{~mm}$ horizontally and $1.0 \mathrm{~mm}$ vertically from the foveal pit, whereas those in patients 6,8 , and 16 extended $2 \cdot 0$ $\mathrm{mm}$ from the foveal pit and further in the temporal region. The latter 3 patients had more profuse flecks.

Patient 4 had the most florid picture (Fig. 2A), in 


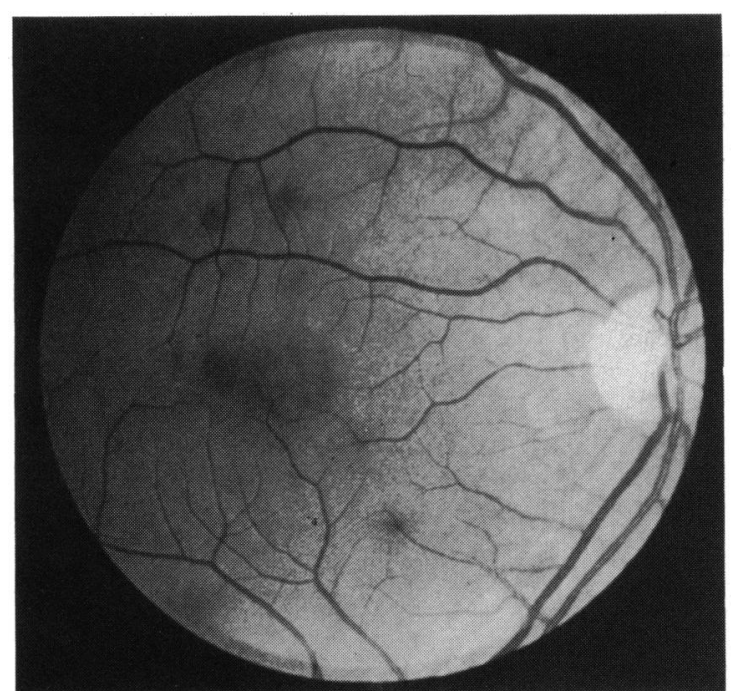

Fig. 1 Patient 10. Sparse macular flecks were seen in 6 patients.

which the flecks had a less regular outline, were up to $100 \mu \mathrm{m}$ diameter and became confluent in parts. They were more extensive, appearing within the central parafoveal area, and extending much further peripherally. Occasionally flecks in cases 4 and 6 formed horizontal linear streaks in the nasal macula and almost vertical linear streaks in the temporal macula, both showing conformation to the nerve fibre layer distribution (Fig. 2A). In general the flecks

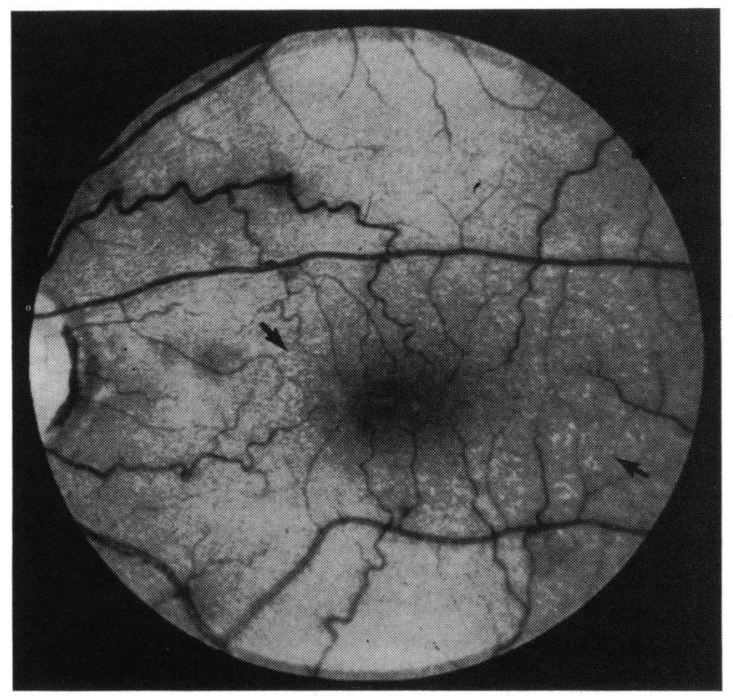

Fig. 2A Patient 4. More profuse flecks were present in 4 patients. Only occasional flecks lie anterior to the retinal vessels and in places the flecks form linear streaks conforming to the nerve fibre pattern (arrows).

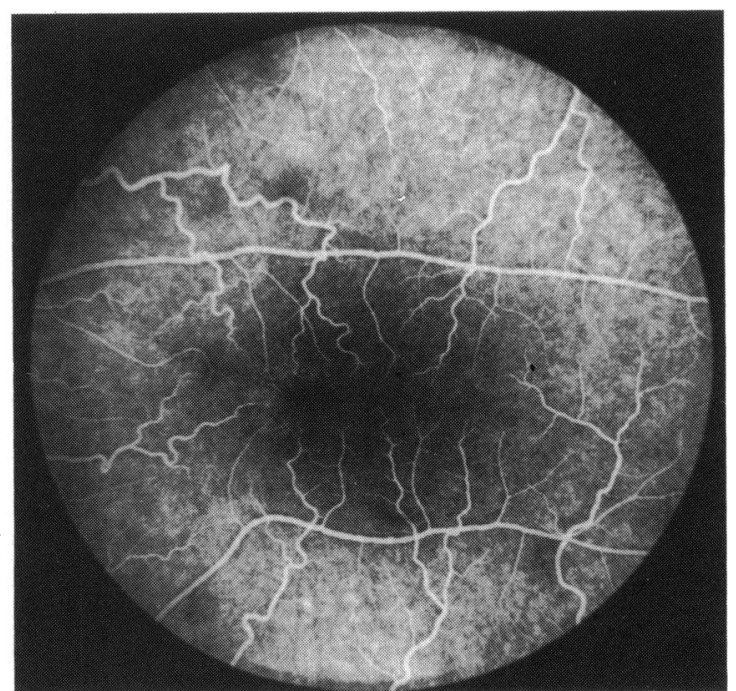

Fig. 2B Patient 4. Fluorescein angiogram. The retinal vessels appear focally attenuated in places and there is an irregular fine spotty hyperfluorescence in the nasal parafoveal area.

tended to spare the retinal vessels, but in case 6 and particularly in case 4 some flecks were seen lying anterior to the vessels (Figs. 2A, 3). In each case the appearance of the flecks was symmetrical, although some cases showed a slightly denser distribution on one side.

The macular flecks in general appeared to transmit fluorescence from both the choroidal and retinal vasculature, though in some places the angiographic appearance of the retinal vessels appeared focally attenuated by the flecks (Fig. 2B). In addition there were a few areas of masking of background choroidal

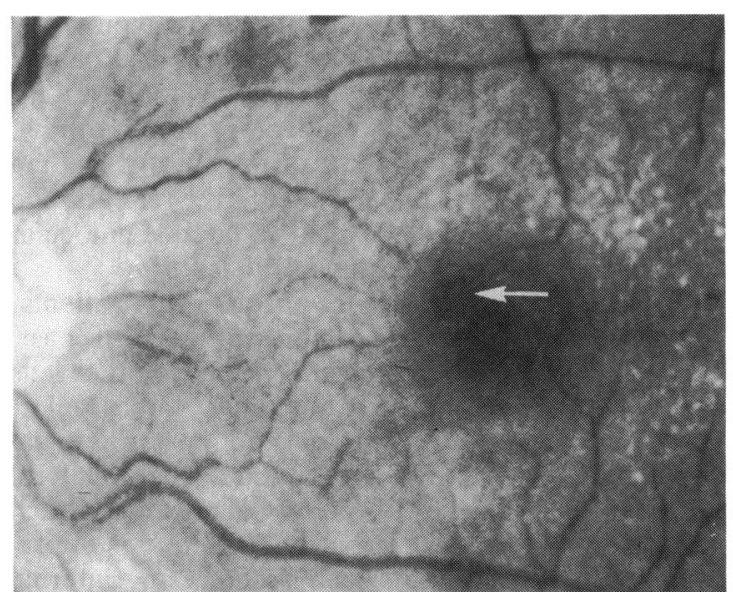

Fig. 3 Patient 6. Simple preretinal membrane showing well defined lacuna (arrow). 


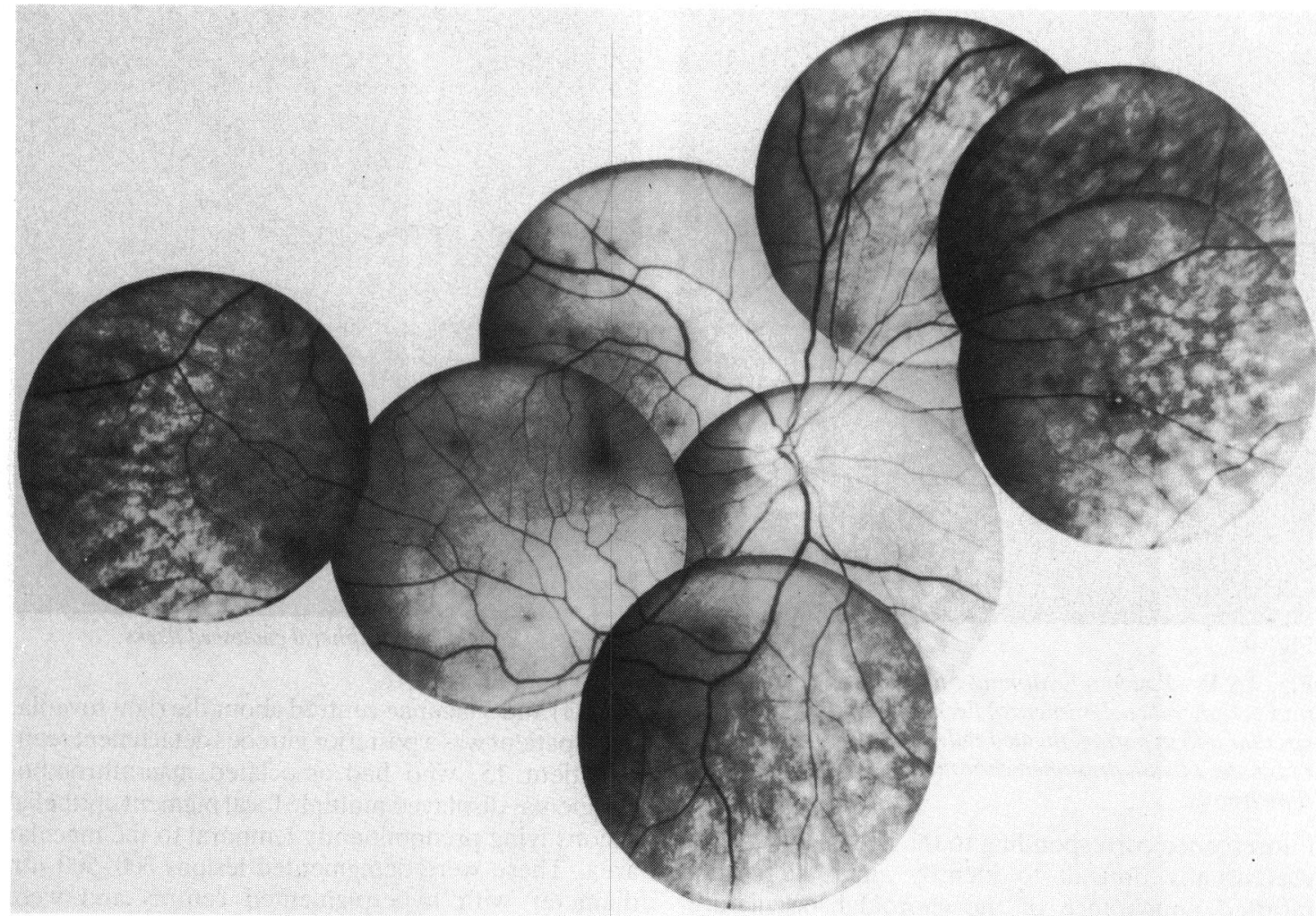

Fig. 4A

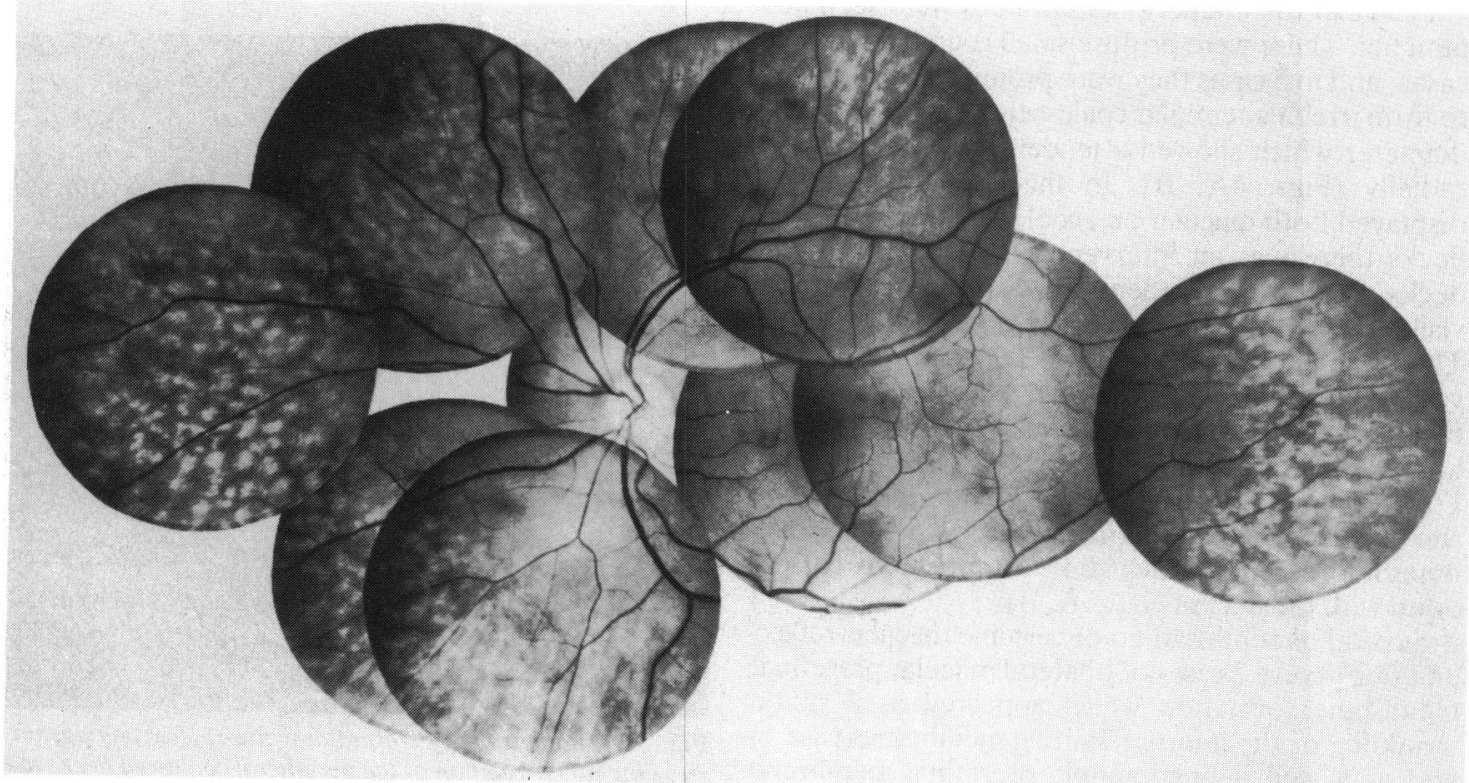

Fig. 4B 


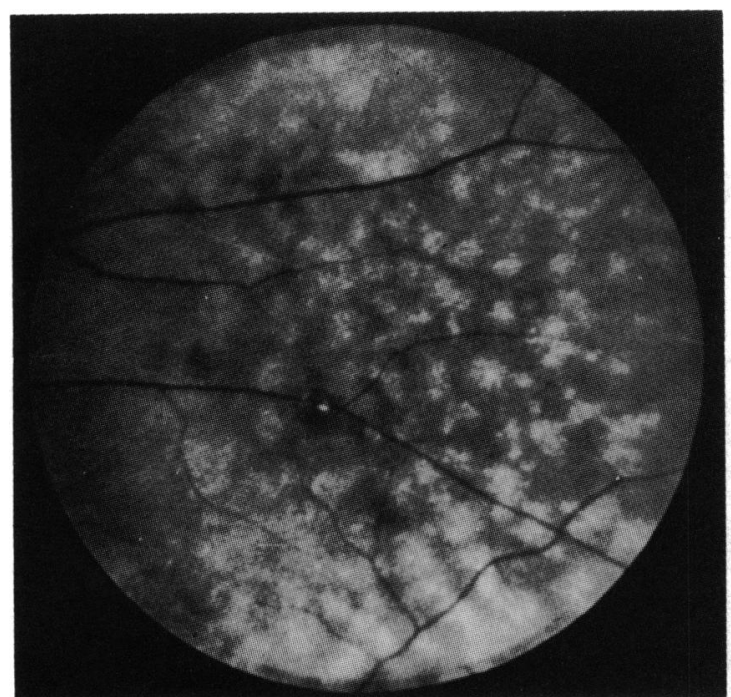

Fig. $4 \mathrm{C}$

Fig. 4A,B Patient 11. Montages to show distribution of mid peripheral coalescences of flecks, which are irregularly circular and in parts elongated radially. C: Peripheral flecks of patient 11 with presumed choroidal infarct of similar dimensions.

fluorescence corresponding to the flecks, though this was usually difficult to identify amid the normal mottled appearance of the choroidal vasculature. One case displayed a bilateral irregular fine spotty hyperfluorescence particularly in the nasal parafoveal area (Fig. 2B).

Flecks in the midperipheral fundus were seen in 9 patients. These were profuse small round lesions in 4 cases, and in 5 cases they were prominent and tended to form irregular circular coalescences of 250-500 $\mu \mathrm{m}$ diameter which showed a tendency to be elongated radially (Figs. 4A, B). In the five patients who displayed both macular and coalesced midperipheral flecks there was an intervening ring area in which flecks were both less dense in distribution and less visible. No flecks were seen anterior to the equator. The peripheral flecks tended to spare the retinal vessels and could rarely be seen overlying them, but owing to the thinness of the retina in this region it was impossible to determine in which layer they lay. Fluorescein angiography of the midperipheral area showed in some photographs a widespread spotty hyperfluorescence which did not appear to correspond with the flecks (Figs. 5A, B).

Several patients had no discernible macular reflex, and there were 2 cases of bilateral macular preretinal membrane formation which appeared as a subtle wrinkling of the internal limiting membrane (case 1) and as a well defined simple preretinal membrane showing one lacuna superonasal to the left foveola

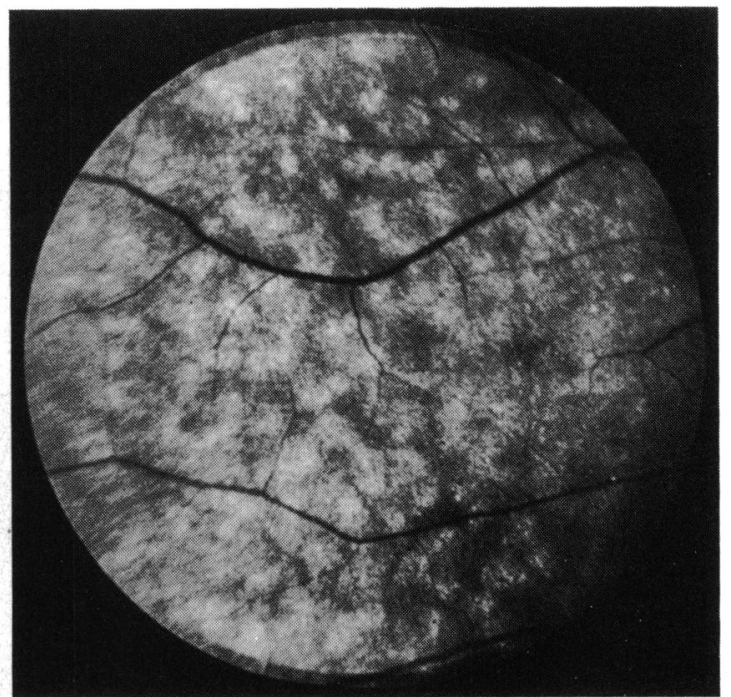

Fig. 5A Patient 11. Peripheral coalesced flecks.

(Fig. 3) and 3 lacunae centred about the right foveola. In no patient was a posterior vitreous detachment seen.

Patient 15, who had associated macrothrombocytopenia, displayed multiple focal pigment epithelial lesions lying predominantly temporal to the macular area. These were depigmented lesions 300-500 $\mu \mathrm{m}$ diameter with hyperpigmented centres and were thought to be choroidal infarcts probably sustained during a period of severe hypertension. Four further patients displayed isolated similar lesions (Fig. 4C).

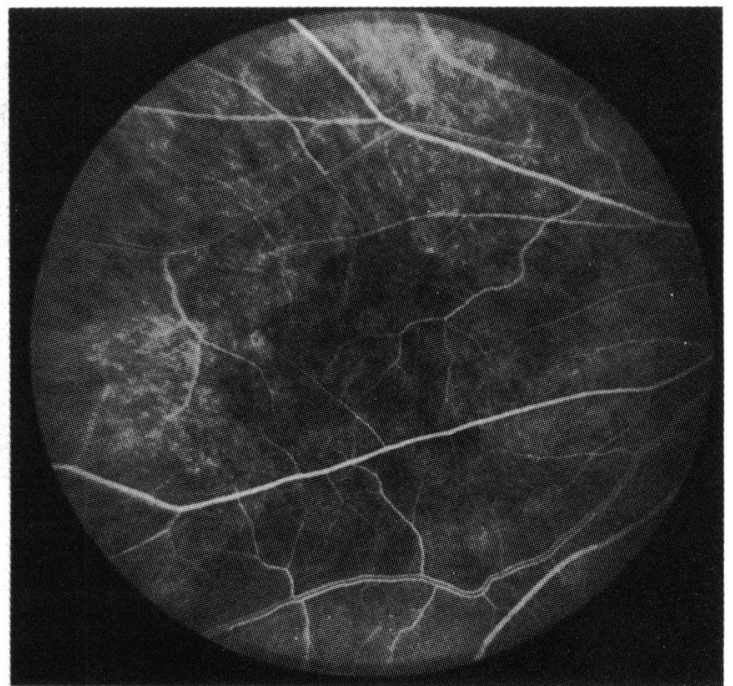

Fig. 5B Patient 11. Corresponding fluorescein angiogram showing no correlation of the peripheral coalesced flecks to the choroidal lobular vasculature. 
Table 2 Serum lipid and lipoprotein levels (mmol/l) in patients 3, 4, 7, 9, 11, 13

\begin{tabular}{lllll}
\hline & & $\begin{array}{l}\text { Alport's } \pm S D, \\
\text { all patients }\end{array}$ & Normal range & $\begin{array}{l}\text { Successfully transplanted } \\
\text { patients only } \\
(4,7,9,13) \pm S D\end{array}$ \\
\hline Triglycerides & Total & $2 \cdot 68 \pm 1 \cdot 59$ & $1 \cdot 38 \pm 0 \cdot 85$ & $2 \cdot 45 \pm 1 \cdot 68$ \\
& VLDL & $1 \cdot 59 \pm 0 \cdot 99$ & $0 \cdot 80 \pm 0 \cdot 76$ & $1 \cdot 69 \pm 1 \cdot 30$ \\
& LDL & $0 \cdot 42 \pm 0 \cdot 17$ & $0 \cdot 31 \pm 0 \cdot 13$ & $0 \cdot 42 \pm 0 \cdot 17$ \\
Cholesterol & HDL & $0 \cdot 19 \pm 0 \cdot 04$ & $0 \cdot 15 \pm 0 \cdot 06$ & $0 \cdot 18 \pm 0 \cdot 03$ \\
& Total & $4 \cdot 92 \pm 1 \cdot 21$ & $5 \cdot 72 \pm 1 \cdot 15$ & $5 \cdot 69 \pm 0 \cdot 67$ \\
& VLDL & $1 \cdot 10 \pm 0 \cdot 69$ & $0 \cdot 44 \pm 0 \cdot 38$ & $0 \cdot 93 \pm 0 \cdot 66$ \\
& LDL & $2 \cdot 83 \pm 0 \cdot 68$ & $3 \cdot 50 \pm 1 \cdot 02$ & $3 \cdot 22 \pm 0 \cdot 64$ \\
\hline
\end{tabular}

$\mathrm{VLDL}=$ very low density lipoproteins. $\mathrm{LDL}=$ low density lipoproteins. $\mathrm{HDL}=$ high density lipoproteins.

Both the ERGs and EOGs were normal in all patients tested.

Biochemical Data (Tables 1, 2, 3)

Both total serum triglycerides and very low density lipoproteins were slightly elevated (Table 2). However, abnormal levels, when repeated, were inconsistently found, and multiple factors including immunosuppressive agents, systemic steroids and renal failure made correlation with the ocular features impracticable. Serum vitamin A levels (Table 1) were raised in 11 patients tested in agreement with previous reports of patients in chronic renal failure and following successful renal transplantation. ${ }^{21-23}$ Plasma amino acids were estimated in 9 patients. The means of the levels in 5

Table 3 Plasma amino acids ( $\mu$ mol/l) in 5 successfully transplanted patients

\begin{tabular}{lccc}
\hline & Normal $\pm S D$ & $\begin{array}{c}\text { Alport's, } \\
\text { mean } \pm S D \\
(n=5)\end{array}$ & $\begin{array}{l}\text { Maximum } \\
\text { normal } \\
\text { concentration }\end{array}$ \\
\hline Taurine & $59 \pm 12$ & $80 \pm 25$ & 256 \\
Aspartic acid & $25 \pm 6$ & $14 \pm 9$ & 100 \\
Threonine & $138 \pm 31$ & $100 \pm 8$ & 336 \\
Serine & $99 \pm 19$ & $86 \pm 19$ & 324 \\
Asparagine & $56 \pm 15$ & $28 \pm 23$ & 52 \\
Glutamic acid & $34 \pm 15$ & $87 \pm 42$ & 142 \\
Glutamine & $640 \pm 58$ & $272 \pm 113$ & 960 \\
Proline & $183 \pm 39$ & $140 \pm 67$ & 435 \\
Glycine & $234 \pm 44$ & $233 \pm 45$ & 515 \\
Alanine & $320 \pm 71$ & $243 \pm 76$ & 675 \\
Citralline & $35 \pm 8$ & $32 \pm 6$ & 63 \\
Aminobutyric acid & $20 \pm 6$ & $9 \pm 4$ & 40 \\
Valine & $225 \pm 40$ & $177 \pm 32$ & 370 \\
Cysteine & $49 \pm 9$ & $28 \pm 13$ & 92 \\
Methionine & $21 \pm 4$ & $19 \pm 1$ & 96 \\
Isoleucine & $60 \pm 12$ & $55 \pm 12$ & 105 \\
Leucine & $115 \pm 23$ & $117 \pm 20$ & 230 \\
Tyrosine & $54 \pm 11$ & $39 \pm 5$ & 196 \\
Phenylalanine & $48 \pm 7$ & $27 \pm 7$ & 182 \\
Ornithine & $58 \pm 14$ & $123 \pm 45$ & 214 \\
Lysine & $186 \pm 36$ & $156 \pm 42$ & 316 \\
Histidine & $88 \pm 16$ & $61 \pm 13$ & 195 \\
Arginine & $82 \pm 17$ & $30 \pm 9$ & 155 \\
\hline
\end{tabular}

successfully transplanted patients (Table 2) show no significant deviation from their normal values, and in no patient was any single amino acid level greater than the normal maximum concentration.

\section{MANAGEMENT}

Lenticonus resulted in myopia in photopic conditions in patient 13, who despite previous attempted spectacle correction was unable to pass the sight test of his driving examination. He achieved OD 6/9, OS $6 / 12$ uncorrected in mesopic conditions but required OD $-2.00 \mathrm{D} /-0.75 \mathrm{D} \times 180$ and $\mathrm{OS}-3.5 \mathrm{D}$ to achieve similar acuities under photopic conditions. Spectacles were preferred to mydriatics, although in those patients with marked lens opacities confined to the axial region dilute topical phenylephrine improved the vision both subjectively and objectively. One patient (patient 15), with profound deafness, was dependent upon lip reading to communicate and underwent unilateral cataract extraction.

\section{Discussion}

The incidence of corneal arcus if found to be slightly higher than that in normal persons ${ }^{24}$ (Table 4), though the samples were too small to be of statistical significance. Of the 8 previously reported cases of arcus in association with lenticonus, 2 (ages 17 and 19 years) ${ }^{1625}$ were aged less than 20 years. Other isolated corneal anomalies have been variously described as superficial white deposits, ${ }^{10}$ bilateral fine punctate changes, ${ }^{26}$ thickening of the anterior layers of the cornea, ${ }^{27}$ and lattice type dystrophy. ${ }^{28}$ Interstitial

Table 4 Incidence of corneal arcus in Alport's syndrome compared with that in normal persons

\begin{tabular}{lll}
\hline Age (years) & $\begin{array}{l}\text { Alport's-present } \\
\text { series }\end{array}$ & Forsius $^{24}$ \\
\hline $0-19$ & $17 \%(1 / 6)$ & $5 \%(2 / 37)$ \\
$20-39$ & $60 \%(3 / 5)$ & $38 \%(40 / 106)$ \\
$30-39$ & $100 \%(5 / 5)$ & $66 \%(57 / 86)$ \\
\hline
\end{tabular}


lipid laden foam cells in renal biopsy specimens are a prominent, although not exclusive, histological feature in Alport's syndrome. This has been proposed as evidence of an abnormality of lipid metabolism. ${ }^{28}$ However, the abundance of foam cells is roughly correlated with the extent of alteration of the glomerular basement membrane ${ }^{29}$ and it is thought that they may result from abnormal glomerular filtration and subsequent tubular reabsorption of lipid material. ${ }^{30}$ Most authors agree on the existence of a correlation between an arcus and hypercholesterolaemia in the general population in these age groups, ${ }^{24}{ }^{31}$ but a comparison of the incidence of arcus in Alport's syndrome with the incidence in other patients in chronic renal failure is required before any further inferences are made.

True anterior lenticonus has been confused with anterior pyramidal opacities, which may be associated with microcornea and anterior chamber cleavage anomalies. ${ }^{3233}$ The literature on lenticonus in Alport's syndrome has been reviewed by Arnott $e t$ $a l .^{6}$ and more recently by Nielsen. ${ }^{7}$ The latter author stated that during the previous 13 years all reported cases of lenticonus which had been investigated were found to have evidence of nephritis and concluded that anterior lenticonus was seen only as a part of Alport's syndrome. A defect of embryogenesis has been proposed as the aetiology of lenticonus, though the usual presence of a clear lens capsule and anterior lens epithelium and the absence of other anterior chamber defects militate against this theory. ${ }^{32}$ The thickness of the lens capsule varies according to the age of the eye and site of the capsule. The thinnest part of the anterior capsule is at the anterior pole and it becomes thickest in a circular area $3 \mathrm{~mm}$ from this. ${ }^{34}$ Several patients in this study could date the onset of their myopia and often stated that it was progressive. However, a well documented increase in the lenticonus has been rarely reported..$^{12} 35$

Spontaneous change of anterior lenticonus to anterior capsular cataract has been well described, ${ }^{2536}$ and this has been observed to follow spontaneous rupture of the capsule overlying the cone.$^{3738}$ It would seem likely therefore that there is an inherent weakness of the anterior lens capsule in lenticonus. ${ }^{39}$ Lenticonus posterior has been sporadically reported in Alport's syndrome. ${ }^{727041}$ Spherophakia has been reported in medical surveys of Alport's syndrome, ${ }^{426}$ in which the coronal diameters of the lens are not commented upon, and it is possible that these patients had a marked anterior lenticonus.

Many lens opacities have been described in association with Alport's syndrome, including anterior and posterior polar, ${ }^{42}$ anterior subcapsular, ${ }^{103842-44}$ posterior subcapsular, ${ }^{27}$ cortical and coronary, ${ }^{47384546}$ and lamellar. ${ }^{27} \mathrm{Up}$ to $75 \%$ of patients under 40 years develop posterior subcapsular lens opacities after renal transplantation, and there are only isolated reports of lens opacities developing in patients on haemodialysis not receiving steroids. ${ }^{47}$ No lens opacity appears to be specific for Alport's syndrome.

Macular flecks in Alport's syndrome were first recorded by Castleman and $\mathrm{Kibbee}^{48}$ and later characterised by Peterson and Albert ${ }^{10}$ as a few flecks in the perifoveal region and by Polak and Hogewind ${ }^{11}$ in a much more profuse distribution around the fovea which they considered to lie at the level of the internal limiting membrane. Fluorescein angiography of the macular region has been reported as always normal. ${ }^{11}{ }^{13}$ Reports of flecks in the mid periphery are less frequent. ${ }^{8-10} 141_{15}$ Peterson and Albert ${ }^{10}$ described multiple small peripheral flecks which they considered to be in the pigment epithelium, and on fluorescein angiography they found tiny hyperfluorescent window defects. This angiographic appearance was confirmed by others, ${ }^{15}$ and the authors of both studies suggested that there was a widespread disturbance of the retinal pigment epithelium. These findings are in accord with this study but were not seen by others. ${ }^{14}$ The combination of both macular and peripheral flecks has only been described in 3 patients. ${ }^{1014}$

The distribution of the macular flecks appears to conform with the thickness of the internal limiting membrane (ILM). Foos ${ }^{49}$ found that both the thickness and the variation in thickness of the ILM increased progressively from the basal zone towards the posterior zone. At the origin of the foveal clivus in an area $1.5 \mathrm{~mm}$ in diameter the ILM gradually thins to $0 \cdot 2 \mu \mathrm{m}$ or less at the fovea ${ }^{50}$ Furthermore the ILM is reduced to as little as $0.5 \mu \mathrm{m}$ over retinal vessels. ${ }^{51}$ The flecks may also be related to the different underlying glial cells, Müller cells producing thick basement membrane and other astrocytes producing thin basement membrane. ${ }^{52}$ The distribution of the coalescences of the peripheral flecks is difficult to explain. However, the only anatomical correlate is the choroidal lobular vasculature,$^{53}$ and in Fig. $4 \mathrm{~B}$ can be seen a presumed choroidal infarct of similar dimensions to the coalescences. Fluorescein angiographic studies in the mid peripheral region in an area of relative choroidal hypoperfusion show the choroidal lobular filling pattern well (Figs. 5A, B). However, the coalescing flecks do not appear to bear any relationship to these. The lack of correlation between the presence of the macular and peripheral flecks suggests that they might have a separate pathogenesis.

Several authors have previously commented upon a weakened macular reflex, ${ }^{7132654}$ and Zylberman et al. ${ }^{14}$ reported a Cellophane light reflex. The occurrence of a well defined bilateral simple pre- 
retinal macular membrane in a 33-year-old patient is highly suggestive of a defect of the ILM. Idiopathic preretinal macular gliosis (IPMG), which has not been reported in patients under 30 years of age, ${ }^{55}$ is associated with a break in the ILM through which glial cells penetrate and proliferate. ${ }^{5657}$ Many patients with IPMG are hypertensive,,$^{55}$ and glial proliferation has been described both clinically following severe hypertensive retinopathy associated with exudative retinal detachment ${ }^{58}$ and also pathologically following severe hypertension. ${ }^{57}$ Although it has been stated that epiretinal membranes are relatively common over cotton-wool spots, ${ }^{59}$ subsequent histological studies of ischaemic retinal infarcts have not revealed any evidence of preretinal membrane. ${ }^{60}$ This has been attributed to glial cell death.$^{61}$ Hypertension may be the aetiology of IPMG in this patient. However, although a weakened macular reflex has been commented upon in patients with chronic renal failure associated with the nephrotic syndrome, further studies in other patients with chronic renal failure are required to determine the significance of IPMG in patients with Alport's syndrome.

Polak and Hogewind ${ }^{11}$ described a photopic ERG at the lower limit of normal in one patient with Alport's syndrome and both low scotopic and photopic ERGs in relatives. Other authors have described similar changes, ${ }^{131462}$ and there is one report of abnormalities of the EOG. ${ }^{15}$ However, the amplitude of the $b$ wave of the ERG is often reduced in patients with chronic renal failure ${ }^{6364}$ and in those on dialysis ${ }^{636567}$ and following renal transplantations. $^{68}$ Both hypertension ${ }^{69}$ and steroid administration $^{70}$ have been reported to alter the $b$ wave amplitude, and low EOGs have been described in patients on haemodialysis. ${ }^{71}$ Therefore no conclusions concerning the electrodiagnostic changes in Alport's syndrome can be made until normal values in this group of patients have been determined.

Macular flecks have been detected in patients whose renal function at the time of examination was normal but who many years later developed renal failure. ${ }^{13}$ The appearance of the flecks bears a remarkable resemblance to many earlier reports of fundus albipunctatus, ${ }^{72}$ which may be stationary without any symptoms, or with stationary night blindness, and in which abnormalities of the ERG and EOG are inconstant. In this disorder the visual acuity is normal or near normal, and the flecks lie in the macular region, generally sparing the fovea and extending towards the equatorial region. They may occur in either region alone and sometimes form a radial distribution, though this is very variable..$^{73}$ Both poor $^{73}$ and irregular ${ }^{74}$ macular reflexes have been described, and the flecks are reported to lie at all neuroretinal levels. Fundus photography confirms that they do not as a rule overlie the retinal vessels. Fluorescein angiography shows a variable picture of occasional masking by the individual flecks and mottled choroidal transmission which does not correlate with the flecks. Most case reports do not contain general medical details, but in 4 cases reported by Nettleship ${ }^{75}$ nearly 100 years ago 2 sisters were noted to be deaf.

The incidence of optic disc drusen in the general population is $0.34 \%,{ }^{76}$ and the much quoted single case described ${ }^{16}$ in association with Alport's syndrome is likely to be coincidental. An increase or disturbance of the macular pigmentation has been noted ${ }^{74}$ but not detailed further. Anisocoria, ${ }^{10}$ iris heterochromia, ${ }^{74}$ and iris atrophy ${ }^{77}$ have been noted, and it is of interest that the sister of patient 5 , who also has Alport's syndrome, displayed a unilateral congenital Horner's syndrome, and one patient had anisocoria.

Although an autosomal dominant inheritance is most commonly described (for discussion and references see Gubler et al..${ }^{78}$ ) some family studies show a sex-linked dominant inheritance ${ }^{79}$ and others are compatible with an autosomal recessive inheritance. $^{78}$ Genetic heterogeneity has been proposed as an explanation of the presence or absence of ocular features among families and also of the varying severity of renal disease. ${ }^{78}$

The characteristic ultrastructural alterations of the glomerular basal lamina in hereditary nephritis are irregular thickening of the basal lamina and replication of the lamina densa with a 'basket weave' pattern in which fibrils of lamina densa interconnect with one another and enclose electron-lucent lacunae which frequently contain small dense particles. ${ }^{29} \mathrm{~A}$ widespread basket weave pattern appears to be specific for hereditary nephritis. ${ }^{80}$ These appearances are not constant, and it is interesting that the renal biopsies of 2 patients (patients 4 and 6) who displayed florid retinal flecks and lenticonus showed no electron microscopy evidence of Alport's syndrome. The cochlear abnormalities characterised by atrophy of the stria vascularis and electron microscopy studies have shown a multilayered basement membrane of the vas spirale.$^{81}$ It has been suggested that there may be a metabolic defect in the biosynthesis or metabolism of collagen with changes in the glomerular basement membrane, cochlea, and capsule of the lens, with the possibility that the collagen may be specific in these 3 places. ${ }^{82}$ Tina $e t$ $a l .{ }^{83}$ have shown an increased excretion of urinary hydroxylysine glycosides (collagen metabolites) in children with Alport's syndrome, suggesting that there is an alteration of collagen metabolism. It seems likely that the retinal internal membrane may be 
additionally primarily involved in this syndrome. One might also make the conjecture that an abnormal basement membrane of the retinal pigment epithelium could result in the pigment epithelial abnormality.

It is concluded therefore that the diagnosis of fundus albipunctatus should not be made in the absence of a full renal investigation and audiometry. The diagnosis of Alport's syndrome can be made on the presence of one of 3 characteristic features. These are anterior lenticonus, macular flecks at the level of the ILM, and peripheral coalescing flecks conforming to Fig. 4. However, the absence of these features does not exclude the diagnosis. Other ocular features occur less regularly and are not specific. It seems likely that Alport's syndrome is due to a widespread defect of certain basement membranes which is irregularly clinically manifest. Further studies into the morphological, biochemical, and biophysical properties of these important extracellular matrices are required. The lens capsule is not only the thickest basement membrane in the body but also the one most easily isolated (for review of this subject see Heathcote and Grant $\left.^{84}\right)$. Cataract extraction is not infrequently required following steroid therapy for renal transplantation, when this basement membrane becomes available for analysis.

I thank the consultant staff of both the adult and paediatric renal units for allowing this study of their patients and particularly Professor S. Cameron for helpful direction to the literature. I am also grateful to Mr D. Watson and Mr R. Daniel for making available the facilities of the Department of Ophthalmology, to Mr N. Dalton, Mr M Mattock, and Dr P. Toseland for the biochemical assays, to $\mathrm{Mr}$ C. Clements and the Department of Medical Photography for photographic assistance, Dr P. Mayles for the electrodiagnostic studies, and to Miss Louise Barker for typing the manuscript.

This study was supported in part by a grant from the Royal National Institute for the Blind.

\section{References}

1 Guthrie LG. Idiopathic or congenital hereditary and familial nephritis. Lancet 1902; i: 1243-6.

2 Hurst AF. Hereditary familial congenital haemorrhagic nephritis occurring in sixteen individuals in three generations. Guy's Hosp Rep 1923; 73: 368-70.

3 Alport AC. Hereditary familial congenital haemorrhagic nephritis. Br Med J 1927; i: 504-6.

4 Sohar E. Renal disease, inner ear deafness and ocular changes. Arch Intern Med 1956; 97: 627-30.

5 Jaworski A. Ein Fall von Lenticonus Anterior und über dessen Entstehen. 1910; 65: 313-7. Summarised in Rones B. ${ }^{32}$

6 Arnott EJ, Crawford MD'A, Toghill PJ. Anterior lenticonus and Alport's syndrome. Br J Ophthalmol 1966; 50: 390-403.

7 Nielsen CE. Lenticonus anterior and Alport's syndrome. Acta Ophthalmol (Kbh) 1978; 56: 518-30.

8 Unger $\mathrm{H}-\mathrm{H}$, Rother K. Netzhautreränderungen beim Alportsyndrom (erbliche Nephropathie mit Innenohrschwerhörigkeit). Ber Dtsch Ophthalmol Ges 1964; 65: 293-8.

9 Bunge H. Mitteilungen aus der Praxis-Für die praxis (Fundus albipunctatus beim Alport-Syndrom). Klin Monatsbl Auenheilkd 1965; 147: 751-3.
10 Peterson WS, Albert DM. Fundus changes in the hereditary nephropathies. Trans Am Acad Ophthalmol Otolaryngol 1974; 78: OP 762-71.

11 Polak BCP, Hogewind BL. Macular lesions in Alport's disease. Am J Ophthalmol 1977; 84: 532-5.

12 Ursui J, Kogo S, Kitahara H. Alport's syndrome. Folia Ophthalmol Jpn 1978; 29: 1012-8.

13 Perrin D, Jungers P, Grünfeld JP, Delous S, Noël L-H, Zenatti C. Perimacular changes in Alport's syndrome. Clin Nephrol 1980; 13: $163-7$.

14 Zylberman R, Silverstone B-Z, Brandes E, Drukker A. Retinal lesions in Alport's syndrome. J Pediatr Ophthalmol 1980; 17: 255-60.

15 Hochesand P, Steinbach PD, Straub E. Augenveränderungen bei Alport-Syndrom. Klin Monatsbl Augenheilkd 1974; 165: 447-52.

16 Friedberg D. Pseudoneuritis und Drusenpapille beim Alport-Syndrom. Klin Monatsbl Augenheilkd 1968; 152: 379-83.

17 Chavis RM, Groshong T. Corneal arcus in Alport's syndrome. Am J Ophthalmol 1973; 75: 793-4.

18 Stevens PR. Anterior lenticonus and the Wardenburg syndrome. Br J Ophthalmol 1970; 54: 621-3.

19 Epstein CJ, Sahud MA, Piel CF, et al. Hereditary macrothrombocytopenia, nephritis and deafness. Am J Med 1972; 52. 299-310.

20 Duke-Elder S. System of ophthalmology. London: Kimpton, 1977: 11: 159 .

21 Smith FR, Goodman DS. The effects of diseases of the liver, thyroid and kidneys on the transplant of vitamin $\mathrm{A}$ in human plasma. J Clin Invest 1971; 50: 2426-36.

22 Yatzidis $\mathbf{H}$, Digenis $\mathbf{P}$, Fountas P. Hypervitaminosis A accompanying advanced chronic renal failure. $\mathrm{Br}$ Med J 1975; iii: 352-3.

23 Kellaher J, Humphrey CS, Horner D, Losowsky MS. Vitamin A and retinal binding protein following renal transplantation in man. Presented at 5th Fat soluble vitamin meeting March 1981, Leeds, UK.

24 Forsius H. Arcus senilis corneae. Acta Ophthalmol (Kbh) 1954; 42 (suppl): 1-78.

25 Tsukahara Y. Zwei Fälle von Lentiglobus anterior. Anhang: Resultäte der Untersuchung der Tätigkeit des vegetativen Nervensystems. Zentralbl Ophthalmol 1931; 24: 171-2.

26 Purriel PD, Diets M, Pascale E, Cestan RS, Borrás A. Ferreira WA, De Lucca A, Fernández L. Familial hereditary nephropathy (Alport's syndrome). Am J Med 1970; 49: 753-73.

27 Perrin D. Le Syndrome d'Alport. Néphropathies héréditaries avec surdité et atteinte oculaire. Ann Oculist (Paris) 1964; 197: 329-46.

28 Kaufmann DB, McIntosh RM, Smith FG, Verrier RL. Diffuse familial nephropathy: a clinicopathological study. J Pediatr 1970; 37: 37-47.

29 Hinglais N, Grunfeld J-P, Bois E. Characteristic ultrastructural lesion of the glomerular basement membrane in progressive hereditary nephritis (Alport's syndrome). Lab Invest 1972; 27: 473-87.

30 Rosen S, Pirani CL, Muchrcke RC. Renal interstitial foam cells: a light and electron microscopic study. Am J Clin Pathol 1966; 45: $32-41$.

31 Varnek L, Schnohr P, Jensen G. Presenile corneal arcus in healthy persons: a possible cardiovascular risk indicator in younger adults. Acta Ophthalmol (Kbh) 1979; 57: 755-65.

32 Rones B. Anterior lenticonus. JAMA 1934; 103: 327-30.

33 Sand BJ, Abraham SV. Anterior lenticonus. Am J Ophthalmol 1962; 53: 636-9.

34 Hogan MJ, Alvarado JA, Weddell JE. Histology of the human eye. Philadelphia: Saunders, 1971; 12: 652-3.

35 Van der Laan. Nagel's Jahresbericht 1880; 2: 369. Summarised in Rones B. ${ }^{32}$

36 Feigenbaum A. The origin of lenticonus. Folia Ophthalmol Orient 1932; 1: 103-10. Summarised in Rones B. ${ }^{32}$ 
37 Ehrlich LH. Spontaneous rupture of the lens capsule in anterior lenticonus. Am J Ophthalmol 1946; 29: 1274-81.

38 Gregg JB, Becker SF. Concomitant progressive deafness. chronic nephritis and ocular lens disease. Arch Ophthalmol 1963: 69: 293-9.

39 Duke-Elder S. System of ophthalmologv London: Kimpton. 1977; 11: 59-61.

40 Asperti G. Lenticono anteriore bilaterale con lenticono posteriore monolaterale in nephritic iperazotemico. Ann Ottalmol 1964; 90: 107-11.

41 Vancea P, Lázárescu D. Contributions à l'étude du lenticone. Ophthalmologica 1958; 135: 67-8.

42 Faggioni R, Scouras J, Streiff EB. Alport's svndrome. Clinicopathological considerations. Ophthalmologica 1972: 165: 1-14.

43 Goldbloom RB. Fraser FC. Waugh D. Aronovitch M. Wigglesworth FW. Hereditary renal disease associated with nerve deafness and ocular lesions. Pediatrics 1957: 20: 241-52.

44 Brownell RD, Walter JR. Anterior lenticonus in familial haemorrhagic nephritis. Arch Ophthalmol 1964: 71: 481-3.

45 Hauser J. Néphropathie chronique héréditaire avec surdité et atteinte oculaire. Schweiz Med Wochenschr 1974: 104: 724-8

46 Rome L, Cuppage FE, Vertes V. Familial haematuric nephritis. Pediatrics 1966; 38: 808-18.

47 Polak BCP. Ophthalmological complications of haemodialysis and kidney transplant. Doc Ophthalmol 1980; 49: 1-96.

48 Castleman B, Kibbee BU. Case records of the Massachusetts general hospital. N Engl J Med 1957: 257: 1231-7.

49 Foos RY. Vitreoretinal juncture: topographical variations. Invest Ophthalmol Visual Sci 1972; 11: 801-8.

50 Yamada E. Some structural features of the fovea centralis in the human retina. Arch Ophthalmol 1969; 82: 151-9.

51 Foos RJ. Vitreoretinal juncture over retinal vessels. Albrecht von Graefes Arch Klin Ophthalmol 1977: 204: 223-34.

52 Fine BS, Yanoff M. Ocular histology. New York: Harper and Row, 1972; 11: 235 .

53 Torczynski E. Tso MOM. The architecture of the choriocapillaris at the posterior pole. Am J Ophthalmol 1976; 81: 428-40.

54 Singh DS, Bisht DB, Kapoor S. Sharma RN. Samkaran K. Majumdar NK. Lenticonus in Alport's syndrome: a family study. Acta Ophthalmol (Kbh) 1977; 55: 164-70).

55 Sidd RJ, Fine SL, Owen SL. Patz A. Idiopathic preretinal gliosis. Am J Ophthalmol 1982; 94: 44-8.

56 Bellhorn MB, Friedman AH, Wise GN. Henkind P. Ultrastructure and clinicopathological correlation of idiopathic preretinal macular fibrosis. Am J Ophthalmol 1975: 79: 366-73.

57 Roth AM, Foos RY. Surface wrinkling retinopathy in eves enucleated at autopsy. Trans Am Acad Ophthalmol Otolarvngol 1971; 75: 1047-58.

58 Buchanan WS, Ellis PP. Retinal separation in chronic glomerulonephritis. Report of a patient cured by bilateral nephrectomies and subsequent successful kidney transplant. Arch Ophthalmol 1964; 71: 182-6.

59 Foos RY. Surface wrinkling retinopathy. In Freeman HM. Hirose T, Schepens CL, eds. Vitreous surgerv and advances in fundus diagnosis and treatment. New York: Appleton-CenturvCrofts, 1977: 23-38.

60 Foos RY. Regional ischaemic infarcts of the retina. Albrecht von Graefes Arch Klin Ophthalmol 1976; 200: 183-94.

61 Yanoff N, Fine BS. Ocular pathology. Hagerstown: Harper and Row, 1975 ; $11: 397-8$.

62 Huch D, Meythaler H. Rix R. Alport-Syndrom' mit Hornhautbeteiligung und Veränderungen des ERG. Klin Monatsbl Augenheilkd 1976; 168: 553-6.

63 Perossini M. Tota G. Electroretinographic findings in chronic uraemics treated with periodic haemodialvsis. Doc Ophthalmol
Proceedings Series 15. 15th ISCEV Symposium. The Hague: Junk. 1978: 257-63.

64 Farkas A. ERG on patients with chronic nephropathy. Doc Ophthalmol Proceedings Series 23. 17th ISCEV Symposium. The Hague: Junk, 5-10 June 1979: 149-52.

65 Mikara A. The studies on the eves of the subjects of renal disease with the treatment by the haemodialysis and the peritoneal dialysis. Report II. The correlation between the EOG and ERG. Nippon Ganka Gakkai Zasshi 1973: 77: 1116-23.

66 Sverák J, Peregrin J. Hejcmanová D. Erben J, Groh J. Logiștic function in the analysis of the ERG in dialysed patients. Doc Ophthalmol Proceedings Series 23. 17th ISCEV Symposium. The Hague: Junk, 5-10 June 1979: 153-7.

67 Müller W. Haase E. Niedlich R. Gauss J. Jung N. Chronic haemodialysis and ERG. Doc Ophthalmol Proceedings Series 23. 17th ISCEV Symposium. The Hague: Junk, 5-10 June 1979: $159-66$.

68 Dróbecka-Brydak E, Moszcýnsha-Kowahka A. Electroretinographic studies in patients after renal transplantation. $D o c$ Ophthalmol Proceedings Series 23. 17th ISCEV Symposium. The Hague: Junk. 5-10 June 1979: 167-70.

69 Henkes HE. Van de Kam JP. Westhoff AJS. Electroretinographic studies in arterial hypertension. Effect of reduction in blood pressure on electrical responses of human retina. Arch Ophthalmol 1954: 52: 221-33.

70 Zimmerman TJ, Dawson WW. Fitzgerald CR. Electroretinographic changes in normal eyes during administration of prednisolone. Ann Ophthalmol 1973; 5: 757-65.

71 Müller W. Thieler H. Electrooculographic findings in cases of regular haemodialysis. Doc Ophthalmol Proceedings Series 23. 17th ISCEV Symposium. The Hague: Junk, 5-10 June 1979: $143-7$

72 Krill AE. Hereditary retinal and choroidal diseases. Hagerstown: Harper and Row. 1977: 2: 739-824.

73 Marmor MF. Fundus albipunctatus: a clinical study of the fundus lesions, the physiological deficit, and vitamin A metabolism. Doc Ophthalmol 1977; 43: 277-302.

74 Krill AE. Klein BA. Flecked retina syndrome. Arch Ophthalmol 1965; 74: 496-508.

75 Nettleship E. Cases of permanent partial night-blindness with unusual ophthalmoscopic changes. Trans Ophthalmol Soc UK 1887: 7: 301-5.

76 Lorentzen SE. Drusen of the optic disc. A clincial and genetic study. Acta Ophthalmol (Kbh) 1966; 90 (suppl): 1-180.

77 Davies PD. Pigment dispersion in a case of Alport's syndrome. $\mathrm{Br}$ J Ophthalmol 1970; 54: 557-61.

78 Gubler M. Levy M, Broyer M, et al. Alport's Syndrome: a report of 58 cases and a review of the literature. Am J Med 1981; 70: $493-505$.

79 O'Neill VN. Atkin CL. Bloomer HA. Hereditary nephritis: a re-examination of its clinical and genetic features. Ann Intern Med 1978; 88: 176-82.

80 Yoshikawa N. Cameron AH, White RHR. The glomerular basal lamina in hereditary nephritis. J Pathol 1981; 135: 199-209.

81 Weidauer $\mathrm{H}$. Arnold $\mathrm{W}$. Consideration to the aetiology of Alport's syndrome. Arch Otorhinolaryngol 1975; 210: 361.

82 McCrory WW. Shibuya M. Worthen HG. Hereditary renal glomerular disease in infancy and childhood. Adv Pediatr 1966; 14: $253-80$.

83 Tina LU, Lou MF, Dizio D. Calcagio PL. Alteration of collagen metabolism in hereditary nephritis. Paediatr Res 1979; 13: 774-6.

84 Heathcote JG. Grant ME. The molecular organisation of basement membranes. Int Rev Connect Tissue Res 1981; 9: 191-264. 